\title{
Peranan cash internal controlling dalam JMSAB menunjang cash management effectivity
}

\author{
Herlina \\ Program Studi Manajemen, STIE Dharma Bumiputera
}

Paper type

Research paper

Keywords: Internal

Control, Cash

Management

\begin{abstract}
Abstrak
Penelitian ini bertujuan untuk mengetahui kecukupan pengendalian internal kas pada Perusahaan SMG. Metode observasi dan teknik pengumpulan data menggunakan angket, dan wawancara. Metode deskriptif digunakan dalam penelitian ini. Berdasarkan hasil pengendalian internal yang dilakukan oleh Perusahaan SMG telah memadai, didukung oleh unsur-unsur lingkungan pengendalian, penilaian risiko, kegiatan pengendalian, informasi dan komunikasi, serta pemantauan. Manajemen kas yang diterapkan oleh Perusahaan SMG telah efektif ini tercermin dalam prosedur mereka untuk penerimaan kas, penerimaan kas kecil, pengeluaran kas, dan pengeluaran uang tunai kecil. Akhirnya, dapat disimpulkan bahwa pengendalian internal kas telah berperan dalam mendukung efektivitas manajemen kas.
\end{abstract}

*Email korespondensi: liena10704@yahoo.com

Pedoman Sitasi: Herlina (2019). Peranan internal controlling dalam menunjang cash management effectivity. Jurnal Manajemen Strategi dan Aplikasi Bisnis, 2(1), 53 - 60
Received: 3 Dec 2018

Accepted: 25 Jan 2019

Online: 15 Feb 2018

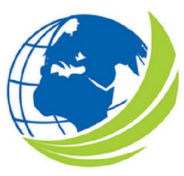

Jurnal Manajemen Strategi dan Aplikasi Bisnis, Vol 2, No.1, April 2019,

pp. 53 - 60

eISSN 2655-237X 


\section{PENDAHULUAN}

Pengendalian merupakan suatu teknik pengawasan yaitu pengawasan keseluruhan dari kegiatan operasi perusahaan, baik mengenai organisasinya maupun sistem atau cara-cara yang digunakan untuk menjalankan perusahaan dan juga alat-alat yang digunakan perusahaan. Adapun pengendalian yang baik, tidak menjamin tidak akan terjadi kesalahan dan penyelewengan dalam perusahaan, tetapi setidak-tidaknya akan mengurangi terjadinya kesalahan dan kecurangan, hal ini dapat diketahui dan diatasi dengan cepat.

Dengan demikian jelaslah bahwa pengendalian intern tidak hanya memeriksa kebenaran angka-angka dan melindungi kekayaan perusahaan dari segi pembukuan saja, tetapi juga memperhatikan struktur organisasi perusahaan, meningkatkan efesiensi kerja dan menganalisis seberapa jauh pelaksanaan kebijakan pimpinan yang telah digariskan oleh perusahaan telah dilaksanakan dengan baik. Suatu pengendalian intern harus selalu dimonitor dan dievaluasi agar manfaat pengendalian intern tersebut senantiasa dapat dipertanggungjawabkan.

Perusahaan dalam menjalankan usahanya harus mengikuti perkembangan situasi ekonomi secara terus menerus. Setiap perkembangan yang terjadi perusahaan harus dapat mengantisipasi masalah secepat mungkin, kemudian menganalisis dan memecahkan dengan cara yang efektif dan efesien, agar dapat mencapai hasil yang diharapkan. Dalam situasi ekonomi yang terus berubah perusahaan harus dapat membuat strategi perencanaan pengelolaan kas yang tepat dan sehat.

Adapun alasan penulis menguraikan pengendalian inten tentang pengelolaan kas yang efektif, karena pengelolaan kas yang efektif itu sangat penting bagi perusahaan. Kas merupakan salah satu aktiva lancar yang paling berharga bagi perusahaan. Apabila pengelolaan kas tidak baik maka hal itu akan dapat menganggu kelancaran aktivitas operasional perusahaan.

Perusahaan dapat mengetahui apakah pengelolaan kas yang ada sudah efektif atau belum dengan cara membandingkan cash flow tahun yang sebelumnya dengan cash flow tahun berjalan atau dapat juga membandingkan cash budget tahun sebelumnya dengan tahun berjalan. Apabila cash flow atau cash budget tahun berjalan sudah lebih baik dari tahun sebelumnya maka pengelolaan kas perusahaan itu sudah efektif. Dan yang menjadi permasalahan dengan Perusahaan SMG yang diteliti oleh penulis adalah bahwa pengendalian intern kas yang ada belum efektif dikarenakan perusahaan tersebut belum memiliki cash budget.

Jika perusahaan memiliki cash budget hal tersebut akan sangat membantu manajemen dalam menetapkan kebijakan, karena cash budget merupakan salah satu alat pengendalian yang dapat digunakan oleh manajemen untuk mencapai pengelolaan kas yang efektif. Berdasarkan latar belakang diatas, peneliti ingin mengadakan penelitian dengan untuk menguji peranan pengendalian intern kas dalam menunjang efektivitas pengelolaan kas pada perusahaan SMG. Adapun maksud penelitian ini dilakukan adalah untuk memperoleh data mengenai Pengendalian Intern Kas dan Efektivitas Pengelolaan Kas.

\section{KAJIAN PUSTAKA}

Pengertian Efektivitas

Definisi efektivitas menurut Mardiasmo (2001;4) efektivitas diartikan sebagai berikut, yaitu; "Efektivitas adalah tingkat pencapaian hasil program dengan target yang ditetapkan. Secara sederhana efektivitas merupakan perbandingan outcome dengan output". Jadi dapat disimpulkan bahwa efektivitas merupakan ukuran tingkat keberhasilan suatu organisasi atau perusahaan untuk mencapai suatu tujuan.

\section{Pengertian Pengendalian Intern Dalam Arti Luas}

Pengertian pengendalian intern dalam arti luas dapat dibagi menjadi dua yaitu pengendalian administrasi dan pengendalian akuntansi. Pengendalian administrasi meliputi rencana organisasi dan semua cara serta prosedur-prosedur yang berhubungan dengan efesiensi usaha dan ketaatan 
terhadap kebijakan pimpinan perusahaan. Pengendalian akuntansi meliputi rencana organisasi dan semua cara serta prosedur-prosedur yang berhubungan dengan pengamanan harta milik perusahaan serta dapat dipercayanya laporan keuangan. Pada perusahaan yang mempunyai ruang lingkup usaha yang cukup besar, seorang pimpinan tidak akan mampu menangani setiap operasi perusahaan secara langsung. Keterbatasan ini menuntut suatu perusahaan untuk memiliki struktur pengendalian internal.

Perlindungan dan pengawasan yang dilakukan oleh struktur pengendalian internal yang memadai dapat mengurangi terjadi penyelewengan baik itu yang bersifat administratif maupun yang bersifat fisik. Kalaupun terjadi, hal ini dapat diketahui dan diatasi dengan cepat oleh manajemen.

Pengertian pengendalian menurut Komarudin (1994;269) adalah sebagai beikut:

"Efektivitas adalah suatu keadaan yang menunjukan tingkat keberhasilan (atau kegagalan) kegiatan manajemen dalam mencapai tujuan yang telah ditetapkan terlebih dahulu".

Adapun pengertian pengendalian menurut Hiro (1997:115) adalah sebagamana berikut:

1. Ada efeknya (akibatnya, pengaruhnya, kesan).

2. Manjur atau mujarab.

3. Dapat membawa hasil, berhasil guna (tentang usaha, tindakan).

4. Mulai berlaku (tentang undang-undang, peraturan).

Dari uraian di atas dapat dikatakan bahwa pengendalian merupakan suatu tindakan yang mempengaruhi keputusan perencanaan dan evaluasi pelaksana. Dengan demikian, pengendalian sebagai suatu proses diperlukan oleh seluruh aktivitas dalam suatu organisasi. Pengendalian merupakan kegiatan membandingkan kinerja yang sebenarnya dengan yang seharusnya atau yang direncanakan. Fungsi pengendalian disini untuk mengukur, mengevaluasi, dan mengusahakan agar setiap pelaksana tindakan berjalan sesuai dengan prosedur yang ditetapkan dalam rangka mencapai tujuan tertentu, selain itu juga untuk mengambil tindakan perbaikan jika diperlukan.

Pengertian Pengendalian Intern Dalam Arti Sempit

Pengertian pengendalian intern dapat dilihat dari arti sempit dan arti luas. Arti sempit merupakan arti dari pengendalian intern yang mula-mula dikenal sebagai internal check, yaitu pengecekan penjumlahan baik, penjumlahan mendatar (cross footing) maupun penjumlahan menurun (footing) yang dilakukan oleh dua orang atau lebih yang bekerja secara independen dengan tujuan untuk memperoleh kebenaran angka. Dalam arti luas, pengendalian intern tidak hanya meliputi pengecekan penjumlahan, tetapi meliputi semua alat yang digunakan manajemen untuk mengadakan pengawasan.

Pengendalian internal sangat penting dalam perkembangan operasi perusahaan, karena masalah-masalah yang timbul sangat kompleks. Dengan demikian, diperlukan suatu pengendalian internal yang baik dan memadai. Sesuai dengan perkembangan zaman dan juga perkembangan dunia usaha, istilah pengendalian internal pun mengalami perkembangan tidak hanya untuk untuk mengawasi kecermatan dan pembukuan, tetapi mempunyai arti luas yaitu meliputi seluruh organisasi perusahaan.

Ikatan Akuntansi Indonesia (2009:319.2) mendefinisikan pengendalian intern sebagai suatu proses yang dijalankan oleh dewan komisaris, manajemen, personel lain entitas yang didesain untuk memberikan gambaran keyakinan memadai tentang pencapaian keandalan laporan, efektivitas dan efesiensi operasi, dan kepatuhan terhadap hukum yang berlaku.

Pengendalian internal merupakan bagian yang sangat penting agar tujuan perusahaan dapat tercapai. Tanpa adanya pengendalian internal, tujuan tujuan perusahaan tidak dapat dicapai secara efektif dan efisien. Semakin besar perusahaan semakin penting pula arti dari pengendalian internal dalam perusahaan tersebut. Secara umum, pengendalian internal merupakan bagian dari masingmasing sistem yang dipergunakan sebagai prosedur dan pedoman operasional perusahaan atau 
organisasi tertentu. Perusahaan umumnya menggunakan Sistem Pengendalian Internal untuk mengarahkan operasi perusahaan dan mencegah terjadinya penyalahgunaan sistem. Definisi pengendalian internal yang dikemukan oleh banyak penulis pada umumnya bersumber dari definisi yang dibuat oleh COSO (The Committee Of Sponsoring Organizations Of Treadway Commission). Pada edisi yang baru, COSO (2013) mendefinisikan pengendalian internal sebagai berikut: "Internal control is a process, affected by an entity's board of directors, management, and other personnel, designed to provide reasonable assurance regarding the achievement of objectives relating to operations, reporting, and compliance"

Pengertian pengendalian internal control menurut COSO tersebut, dapat dipahami bahwa pengendalian internal adalah proses, karena hal tersebut menembus kegiatan operasional organisasi dan merupakan bagian integral dari kegiatan manajemen dasar. Pengendalian internal hanya dapat menyediakan keyakinan memadai, bukan keinginan mutlak. Hal ini menegaskan bahwa sebaik apapun pengendalian internal itu dirancang dan dioperasikan,hanya dapat menyediakan keyakinan yang memadai, tidak dapat sepenuhnya efektif dalam mencapai tujuan pengendalian internal meskipun telah dirancang dan disusun sedemikian rupa dengan sebaik baiknya. Bahkan bagaimanapun baiknya pengendalian internal yang ideal di rancang, namun keberhasilannya bergantung pada kompetisi dan kendala dari pada pelaksanaannya dan tidak terlepas dari berbagai keterbatasan.Pentingnya Pengendalian Internal Untuk menciptakan pengendalian akuntansi yang baik, diperlukan pengendalian akuntansi meliputi rencana organisasi serta prosedur dan catatan keuangan yang untuk meyakinkan bahwa (Theodarus 2012:88):

Transaksi yang dilakukan sesuai dengan persetujuan pemimpin. Transaksi dicatat dengan benar dan layak sehingga memungkinkan dibuatnya ikhtisar keuangan yang sesuai dengan prinsip akuntansi dan kriteria lain yang sesuai. Jumlah aktiva atau harta perusahaan yang ada dalam catatan perusahaan dicocokan dengan harta yang ada pada waktu tersebut dan mengambil tindakan yang sewajarnya jika terjadi perbedaan.

Manfaat Pengendalian Intern bagi Manajemen

Semakin luas daerah lingkup perusahaan mengakibatkan manajemen tidak dapat melakukan pengawasan secara langsung atau secara pribadi terhadap jalannya operasi perusahaan. Sedangkan tanggung jawab yang utama untuk menjaga keamanan hak milik perusahaan dan untuk mencegah terjadinya kesalahan-kesalahan serta kecurangan-kecurangan terletak ditangan manajemen. Oleh karena itu, bagi manajemen mempertahankan terus adanya pengendalian intern termasuk sistem pelaporan yang baik adalah sangat diperlukan, menyerahkan dan mendelegasikan tanggung jawab dengan tepat. Beberapa peranan penting pengendalian intern dalam perusahaan menurut Mulyadi (2010:80), yaitu:

Tidak mungkin lagi bagi manajemen untuk melakukan kegiatan transaksi sampai pada tahap penyelesaian secara sendirian, sehingga dapat mengurangi terjadinya pencurian. Dengan adanya penyerahan tugas dan wewenang akan menimbulkan pertanggungjawaban, pengendalian dapat dipakai sebagai ukuran untuk menilai kebijakan yang telah ditetapkan sebelumnya oleh manajemen.

Dengan pengendalian intern, maka kegiatan dapat dikoordinasikan dan harta perusahaan dapat dilindungi. Dapat dicegah terjadinya kesalahan-kesalahan dan penyelewengan-penyelewengan karena dengan pengendalian intern akan terdapat arus kegiatan yang teratur dari petugas ke petugas yang berikutnya mengulangi pekerjaan petugas sebelumnya. Dalam waktu yang singkat dapat mengetahui dan menemukan kesalahan-kesalahan dan penyelewengan-penyelewengan yang terjadi, dan menentukan siapa yang bertanggung jawab atas kesalahan dan penyelewengan yang terjadi.

Berdasarkan uraian di atas tanggung jawab untuk menyusun dan melaksanakan pengendalian intern terletak pada manajemen, dan pengendalian intern ini merupakan alat untuk meletakan kepercayaan akuntan dalam menjalankan tugasnya. 
Hubungan antara Pengendalian Intern dengan Efektivitas Pengelolaan Kas

Sistem pengendalian intern yang dirancang dengan baik akan dapat mendorong ditetapkannya kebijakan manajemen. Selain itu menurut Haryono Yusuf (2011:4) keuntungan sistem pengendalian intern yang dirancang dengan baik adalah sebagai berikut:

1. Mendorong terciptanya efisiensi operasi.

2. Melindungi aktiva perusahaan dari pemborosan, kecurangan, dan pencurian.

3. Menjamin terciptanya data akuntansi yang tepat dan bisa dipercaya.

Dari kutipan tersebut di atas disebutkan bahwa salah satu keuntungan yang diperoleh dari suatu sistem pengendalian intern yang dirancang dengan baik yaitu dapat melindungi aktiva perusahaan dari pemborosan, kecurangan, dan pencurian dalam hal ini aktiva tersebut adalah aktiva berupa kas.

Efektivitas pengelolaan kas dapat dinilai jika ketentuan-ketentuan, srandar-standar dan kebijakan-kebijakan yang telah ditetapkan dijalankan dengan sepenuhnya oleh setiap personil yang ada dalam perusahaan tersebut. Pengelolaan kas juga dapat diartikan efektif jika tujuan dari pengelolaan kas itu sendiri tercapai.

Dengan demikian semakin memadai pengendalian intern yang ada dalam perusahaan dan semakin dipatuhinya pengendalian intern tersebut oleh seluruh personil perusahaan, maka semakin efektif pengelolaan kas yang dilakukan oleh pihak manajemen perusahaan. Sebaliknya jika pelaksanaan pengendalian intern banyak yang menyimpang dari yang semestinya, maka efektivitas pengelolaan kas dapat dikatakan masih meragukan.

\section{METODE PENELITIAN}

Tempat dan Waktu Penelitian

Penelitian dilaksanakan pada SMG, Jakarta Utara pada bulan Juli 2017 sampai dengan Juni 2018.

Desain Penelitian

Metode yang digunakan dalam penelitian ini adalah metode deskriptif kualitatif yaitu penelitian dengan mengumpulkan data sesuai dengan keadaan yang sebenarnya, serta memberikan gambaran dan analisis mengenai masalah yang ada. Sedangkan penelitiannya dengan menggunakan pendekatan studi kasus, artinya penelitian dilakukan pada satu objek penelitian. Data yang dikumpulkan meliputi data primer dan data sekunder.

\section{HASIL DAN PEMBAHASAN}

Peranan Pengendalian Intern Kas Dalam Menunjang Efektivitas Pengelolaan Kas

Setelah melakukan penelitian penulis berpendapat bahwa pengendalian internal kas pada SMG memadai, karena pengendalian internal yang dijalankan telah memenuhi unsur-unsur pengendalian internal yaitu:

1. Lingkungan Pengendalian. Pada umumnya lingkungan pengendalian yang ada di SMG telah memadai, hal ini tercermin dari pelaksanaan unsur -unsur lingkungan pengendalian. SMG telah mempunyai struktur organisasi yang mengatur dengan jelas garis komando di dalam perusahaan, pendelegasian wewenang dan tanggung jawab yaitu setiap bagian di dalam perusahaan telah mengetahui dengan jelas tugas dan tanggung jawab masing-masing, dan adanya kebijakan perusahaan seperti pemberian bonus kepada karyawan yang berprestasi, pemberian tunjangan-tunjangan dan adanya pemberian cuti secara berkala.

2. Perkiraan Risiko yang Timbul. Risiko yang mungkin timbul telah diidentifikasi, dianalisis, dan dikelola dengan baik oleh SMG, sehingga dapat mempermudah pelaksanaan pengendalian internal dan mengurangi penyimpangan di SMG. Hal ini tercermin dari adanya pelatihan terhadap karyawan yang dapat berupa pendidikan keahlian dan pendidikan lainnya yang dapat meningkatkan keahlian karyawan serta adanya masa training bagi 
karyawan baru selama tiga bulan. Walaupun masih dapat kelemahan dalam sistem absensi yang masih dilakukan secara manual, sehingga dapat menyebabkan adanya kecurangankecurangan dalam sistem absensi yang terjadi akibat tidak terpantau.

3. Aktivitas Pengendalian. Aktivitas SMG telah memadai, tercermin dari pelaksanaan unsurunsur aktivitas pengendalian dengan baik oleh bagian yang ada di SMG, seperti adanya pemisahan antara fungsi otorisasi, fungsi pengawasan, fungsi pencatatan, dan fungsi penyimpanan.

4. Infomasi dan Komunikasi. Informasi dan komunikasi pada SMG telah berjalan dengan baik, hal ini terlihat dari penyususnan dan penyampaian infomasi serta komunikasi antara bagianbagian yang terkait di SMG, sehingga membantu manajemen dalam pelaksanaan pengendalian intern.

5. Pemantauan. Pemantauan pada SMG telah berjalan dengan cukup baik, hal ini terlihat dari adanya tindakan evaluasi dan tindakan koreksi jika terdapat kelemahan, sehingga akan semakin menyempurnakan pengendalian intern yang ada pada SMG.

\section{Efektivitas Pengelolaan Kas}

Setelah melakukan penelitian penulis berpendapat bahwa pengelolaan kas pada SMG memadai, karena adanya pemisahan tugas atau fungsi dalam:

1. Penerimaan Kas. Telah adanya pemisahan tugas dan tanggung jawab yang jelas, dimana dalam penerimaan kas tidak hanya melibatkan satu bagian saja. Sehingga tidak akan terjadi kecurangan yang dilakukan satu pihak.

2. Penerimaan Kas Kecil. Penerimaan kas kecil melibatkan tiga bagian yaitu Bagian Keuangan, Bagian Akuntansi dan kasir. Untuk mengisi kembali dana kas kecil kasir harus mengisi terlebih dahulu formulir pengisian kembali dana kas kecil yang dilampiri dengan bukti-bukti transaksi pengeluran kas yang dapat berupa kwitansi, faktur-faktur dan lain sebagainya.

3. Pengeluaran Kas. Pengeluaran kas untuk membayar gaji pegawai, sebelum Bagian Keuangan melakukan pembayaran gaji kepada para karyawan Bagian Keuangan terlebih dahulu menerima laporan dari kasir mengenai gaji setiap karyawan setelah Bagian Keuangan memeriksa semua laporan mengenai gaji para karyawan. Bagian Keuangan kemudian mentransfer gaji para karyawan kedalam rekening masing-masing karyawan. Pembayaran gaji para karyawan dengan cara transfer selain efektif dan efektif juga mengurangi resiko berupa kehilangan dan perampokan dari pihak yang tidak bertanggungjawab.

4. Pengeluaran Kas Kecil. Bagian yang membutuhkan pengeluaran kas kecil harus mengisi terlebih dahulu formulir permintaan pengeluaran kas kecil rangkap dua. Lembar pertama untuk kasir dan lembar kedua untuk bagian yang membutuhkan. Sebelum melakukan pengeluaran kas kecil formulir permintaan pengeluaran kas kecil harus mendapat otorisasi terlebih dahulu dari Bagian Keuangan. Setelah mendapat persetujuan, bagian yang membutuhkan membawa formulir yang telah disetujui oleh Bagian Keuangan. Kasir akan mengeluarkan kas sebesar jumlah yang tercantum dalam formulir permintaan pengeluaran kas kecil yang telah disetujui oleh Bagian Keuangan.

Efektivitas pengelolaan kas dapat dicapai jika hal-hal berikut ini dapat dihindari atau dikurangi.

1. Lapping. Terdapat pemisahan fungsi antara bagian penyimpanan dengan bagian pencatatan dan uang yang diterima pada hari itu langsung disetorkan ke bank atau paling lambat keesokan harinya. Bagian Keuangan selalu memeriksa transaksi penerimaan dan pengeluaran kas yang ada pada kasir. Kemudian Bagian Keuangan membuat laporan kepada Kepala Bagian Akuntansi dan Keuangan. Di SMG tidak pernah terjadi penggelapan kas dengan cara lapping. 
2. Tidak melaporkan penjualan. Bagian Keuangan selalu memeriksa hasil penjualan setiap hari dengan melakukan cross check antara catatan menurut kasir dan catatan pengambilan barang digudang. Kemudian Kepala Bagian Akuntansi dan Keuangan akan mencocokannya dengan catatan yang ada pada Bagian Akuntansi, sehingga tidak memungkinkan kasir untuk tidak melaporkan penjualan.

3. Membukukan pengeluaran palsu. Setiap pengeluaran yang terjadi di SMG harus diotorisasi oleh Bagian Keuangan dengan memeriksa kebenarannya terlebih dahulu, sehingga kasir atau bagian lain sulit untuk membukukan pengeluaran palsu.

4. Kitting. Kecurangan dengan cara kitting tidak pernah terjadi, karena SMG hanya menggunakan satu bank saja dan selalu di adakan rekonsiliasi antara saldo menurut bank dan catatan saldo perusahaan. Hal ini dapat menghindari penyalahgunaan kas dengan cara kitting.

5. Mencantumkan jumlah yang salah pada buku kas. Seperti yang telah dijelaskan diatas, Bagian Keuangan selalu mencocokan jumlah kas yang ada pada kasir dengan bukti-bukti transaksinya. Kemudian Kepala Bagian Akuntansi dan Keuangan mencocokannya kembali dengan catatan yang ada pada Bagian Akuntansi, sehingga kesalahan mencantumkan jumlah kas kecil sekali karena tidak hanya diperiksa oleh satu bagian saja.

\section{KESIMPULAN}

Berdasarkan hasil penelitian dan pembahasan yang telah dikemukakan sebelumnya, penulis dapat menarik simpulan sebagai berikut:

1. Pengendalian intern kas yang ada di perusahaan telah memadai, hal ini tercermin dalam pelaksanaan pengendalian intern yang ada pada SMG, yaitu:

- Terdapat struktur organisasi yang didalamnya terdapat uraian tugas yang mencerminkan tanggung jawab setiap bagian yang ada di dalam perusahaan, sehingga mendorong karyawannya untuk mematuhi setiap peraturan yang ada.

- Adanya seleksi terhadap calon karyawan yang baru untuk mendapatkan karyawan yang berkualitas dan menggunakan sistem komuperisasi dalam pembuatan bukti transaksi.

- Terdapat pemisahan bukti otorisasi, pengawasan, pencatatan, dan penyimpanan kas. Adanya pelaksanaan review pada SMG untuk menilai pelaksanaan prosedur, khususnya prosedur yang berhubungan dengan kas.

- Adanya otorisasi dari pejabat yang berwenang untuk setiap transaksi pengeluaran kas. Pelaksanaan penjurnalan oleh Bagian Akuntansi dilakukan berdasarkan dokumen yang telah di isi dan di otorisasi di sertai bukti-bukti pendukung.

- Pelaksanaan monitoring terhadap laporan pengeluaran dan penerimaan kas yang diterima oleh pejabat terkait.

- Adanya brangkas dan lemari khusus tempat penyimpanan uang dan dokumen-dokumen perusahaan yang terkunci dan menggunakan kode-kode khusus serta tidak dapat dibuka oleh sembarang orang.

2. Pengelolaan kas yang dilakukan di SMG telah efektif hal ini tercermin dari:

- Terdapat pemisahan fungsi antara bagian penyimpanan, bagian pencatatan, yang mengotorisasi, dan yang memeriksa, sehingga dapat meminimalkan kecurangan atau penyalahgunaan kas yang ada di dalam perusahaan.

- Seluruh pendapatan yang diterima pada hari itu langsung disetorkan ke bank dan saldonya selalu di periksa oleh Kepala Bagian Akuntansi dan Keuangan.

- Bagian Keuangan selalu memeriksa transaksi penerimaan dan pengeluaran kas yang ada pada kasir, sehingga penggelapan kas dengan cara lapping dapat dihindari. 
3. Pengendalian intern kas telah berperan dalam menunjang efektivitas pengelolaan kas, hal ini dapat dilihat dari:

- Terdapat pemisahan fungsi antara bagian penyimpanan dan bagian pencatatan serta uang yang diterima hari itu langsung disetorkan ke bank atau paling lambat keesokan harinya.

- Bagian keuangan selalu memeriksa hasil penjualan dengan melakukan cross check antara catatan menurut kasir dan catatan pengambilan barang di gudang.

- Dengan adanya otorisasi dari pejabat berwenang untuk setiap pengeluaran, sehingga tidak terjadi pengeluaran yang tidak semestinya dan dengan adanya SMG telah meminimalkan risiko pencurian uang tunai dan penyalahgunaannya oleh orang-orang yang tidak bertanggung jawab.

- Pencocokan antara catatan saldo menurut bank dengan catatan saldo menurut pada perusahaan oleh Kepala Bagian Akuntansi dan Keuangan.

- Bagian Keuangan selalu mencocokan jumlah kas yang ada pada kasir dengan bukti-bukti transaksinya, kemudian Kepala Bagian Akuntansi dan Keuangan mencocokan kembali dengan catatan menurut Bagian Akuntansi.

\section{REFERENSI}

A Hall, James. (2011).Accounting Information System, Edisi ke 4, Salemba Empat. Jakarta. Bastian, Indra. (2007). Sistem Akuntansi Sektor Publik. Edisi 2.Jakarta: Salemba Empat. Amin W.T. (2005). Internal Auditing (Suatu Pengantar); Jakarta: Harvaindo.

Arens dan Lubblecke. (2001). Auditing Pendekatan Terpadu, Edisi Indonesia; Jakarta: Salemba Empat.

Modul Akuntansi Sektor Publik Bab 9 Sistem Akuntansi Pendapatan dan Penerimaan Kas pada Sektor Publik.

Modul Akuntansi Sektor Publik Bab 10 Sistem Akuntansi Pengeluaran Kas pada Sektor Publik.

Mulyadi, (2000), Akuntansi Biaya, Aditya Media; Yogyakarta.

Mulyadi, (2002), Pemeriksaan Akuntansi; Jakarta: Salemba Empat.

Peraturan Menteri Dalam Negeri Nomor 13 Tahun 2006 Tentang Pedoman Pengelolaan Keuangan Daerah .

Peraturan Menteri Dalam Negeri Nomor 59 Tahun 2007, Perubahan atas

Peraturan Menteri Dalam Negeri Nomor 13 Tahun 2006 Tentang Pedoman Pengelolaan Keuangan Daerah.

Ricard D Irwin Inc: (2002). Sistem Pengendalian Manajemen, Alih Bahasa Agus Maulana; Jilid II Cetakan Pertama;Jakarta, Bina Rupa Aksara.

Sudjana M.A, (2001); Teknik Analisis Data Kualitatif; Bandung:Tarsito.

Sugiyono, (2010), Metode Penelitian Bisnis; Bandung:Alfabeta.

Soemarso SR, (2002), Akuntansi Suatu Pengantar; Jakarta: Rineka Cipta.

Undang-Undang Republik Indonesia Nomor 32 Tahun 2004 Tentang Pemerintahan Daerah

Baridwan, Z. (2000), Intermediate Accounting, Yogyakarta: BPFE, Cetakan Ketujuh.

\section{PROFIL PENULIS}

Herlina adalah dosen di Program Studi Manajemen, STIE Dharma Bumiputera 